\title{
Changes in Semen, Hormonal profile and Testicular Morphology of West African Dwarf Goat Bucks treated with Danazol
}

\author{
Lukman Oladimeji Raji ${ }^{1, a, *}$, Mohammed Babashani ${ }^{2, b}$, Ganiyu Jimoh Akorede ${ }^{3, c}$, \\ Aishat O Olatunji ${ }^{3, d}$, Fatima Sanusi ${ }^{4, e}$, Yusuf Idris ${ }^{5, f}$, Khalid Tahlia Biobaku ${ }^{3, g}$ \\ ${ }^{1}$ Department of Theriogenology and Production, University of Ilorin, Ilorin, Nigeria \\ ${ }^{2}$ Veterinary Teaching Hospital, Ahmadu Bello University, Zaria, Nigeria \\ ${ }^{3}$ Department of Pharmacology and Toxicology, University of Ilorin, Ilorin, Nigeria \\ ${ }^{4}$ Department of Physiology and Biochemistry, University of Ilorin, Ilorin, Nigeria \\ ${ }^{5}$ Department of Medical Pharmacology and Biochemistry, Kwara State University, Molete, Nigeria \\ *Corresponding author
}

\section{A R T I C L I N F O A B S T R A C T}

Research Article

This study was carried out to investigate the changes in semen characteristics, hormonal profile and testicular morphometry of West African Dwarf (WAD) goat bucks treated with danazol. For this purpose, eighteen matured WAD bucks average of about two years were randomly divided into groups $\mathrm{A}, \mathrm{B}$ and $\mathrm{C}$ comprising of six bucks per group. Group $\mathrm{A}$ was the control while $\mathrm{B}$ and $\mathrm{C}$

Received : 27/06/2020

Accepted : 21/10/2020 bucks were given danazol at a dose rate of $20 \mathrm{mg} / \mathrm{kg}$ body weight orally daily for four weeks. The group B bucks' testes were harvested thereafter for gross and histo-morphometric studies while those of group $\mathrm{C}$ were left intact but danazol treatment was withdrawn for four more weeks. The bucks' semen samples (collected by electro-ejaculation) and hormonal samples (taken via the jugular vein) were analyzed. The semen characteristics studied included color, volume, mass activity, motility, percentage normal live-dead ratio, morphology and concentration; while the

Keywords:

Danazol

Contraceptive

Semen

West African dwarf bucks

Sperm cells hormones studied included testosterone, follicle stimulating hormone and luteinizing hormone. Results show that there were significant decreases in semen characteristics of group B and C bucks compared with those of group A in the first four weeks. The semen characteristics of the group C bucks were reversed to normal range (similar to those of group A bucks) two weeks after danazol treatment was withdrawn. Similar results were observed with the hormonal studies. In conclusion, danazol caused a reversed reduction in sperm cells characteristics suggesting its possible use as a contraceptive in WAD goat bucks.

\section{Introduction}

Danazol is a synthetic attenuated androgen that has been used especially in human (females) to manage various disease conditions such as endometritis, fibrocystic breast diseases, autoimmune thrombocytopaenia, amongst others diseases (Alvarez et al., 2011; Lauro et al., 2011). It is not popularly used in males but it has been documented to possess inhibitory effect on the release of reproductive hormones including the Follicle Stimulating Hormones (FSH) and Luteinizing Hormone (LH) from the anterior pituitary (Van Kroonenburgh et al., 1986). These hormones play important roles on testicular functions; the FSH acts on the sertoli cells (which are the nurse cells for spermatogenic cells) while the LH acts on leydig cells (which is the site of production of testosterone). The FSH and LH acts synergistically to promote spermatogenesis (Oduwole et al., 2018). Hence, inhibition of these hormones will have effect on testicular function and the rate of sperm production. There is dearth of literature on the effect of danazol on spermatogenesis and associated gonadotrophins in bucks of a model livestock; therefore, paramount to carry out research to ascertain its clinical utility, safety and fill the gap particularly in relation to male animals and livestock production. This is because in modern livestock production, non-invasive methods of 
controlling reproduction are being employed. For instance, drug therapy is now being used to replace invasive techniques such as castration in order to reduce health risk and cost associated with surgical and post-surgical exercises (Jana and Samanta, 2011; Ansari et al., 2017). Therefore, this research was carried out to investigate the effect of danazol on semen characteristics, hormonal profile, testicular gross and histomophometry and its possible use as a contraceptive in WAD goat bucks.

\section{Materials and Methods}

\section{Ethical Approval}

Ethical approval was sought following presentation of proposal seminar at the University of Ibadan, Oyo state, Nigeria. The University thus granted approval as part of a thesis. The procedures and conduct of the research were scrutinized to conform with international standards for conducting research on small ruminants.

\section{Animal Management and Experimental Design}

Eighteen matured and reproductively active WAD bucks between the ages of one and half to two years with an average Body Weights (BW) of $11.7 \pm 0.6 \mathrm{~kg}$ and of universal body score of 3 were used for this study. The bucks were housed at the goat unit of the Department of Veterinary Surgery and Theriogenology, Michael Okpara University of Agriculture, Umudike. They were stabilized for four weeks prior to the commencement of the experiment. The bucks were randomly divided into groups $\mathrm{A}, \mathrm{B}$ and $\mathrm{C}$ comprising of six bucks per group. Group A was the control while $\mathrm{B}$ and $\mathrm{C}$ bucks were given danazol at a dose rate of $20 \mathrm{mg} / \mathrm{kg}$ body weight orally daily for four weeks. The group B bucks' testes were harvested thereafter for gross and histo-morphometric studies while those of group $\mathrm{C}$ were left intact but danazol treatment was withdrawn for four more weeks.

\section{Semen Sample Collection}

Semen samples were collected by electro-ejaculation method as described earlier (Bitto et al., 2000) from bucks in the three groups weekly for four consecutive weeks. Thereafter, semen samples were further collected from bucks in group $\mathrm{C}$ for four more weeks. The semen characteristics evaluated included color, volume, mass activity, motility, percentage normal live-dead ratio, morphology and concentration. All semen samples were analyzed as described earlier by Bitto et al., 2000; Raji and Ajala (2015).

\section{Serum Sample Collection and Hormonal Analysis}

Blood samples were collected twice in a week from all the group bucks for four weeks from the jugular vein using needle and syringe of guage 21 into plain sample bottles. The blood samples were allowed to clot then centrifuged at 3000 revolutions per minute (rpm) for 30 minutes to separate serum from the plasma. The serum samples were carefully decanted into another plain bottle and stored in a deep freezer at $-40^{\circ} \mathrm{C}$ until used. These serum samples were assayed for serum concentration of testosterone, follicle stimulating hormone (FSH) and luteinizing hormone (LH) level using Enzyme-Linked Immunosorbent Assay (ELISA) kits.

\section{Gross Morphometric Studies}

The testes of group A bucks and six of group B bucks were harvested routinely. The weight and volume of the testes of the groups A and B bulks were taken using digital weighing balance (OHAUS ${ }^{\circledR}$ ) and the water displacement method respectively as described earlier (Mbaeri et al., 2012; Raji and Ajala 2015; Raji et al., 2016).

\section{Histo-Morphometric Studies}

Histomorphometric studies were carried out on the group A and B bucks as described earlier (Akinloye et al., 2002; Olukole et al., 2014; Raji et al., 2015). The histomorphometric parameters taken for the testes were Seminiferous Tubular Diameter (STD), Seminferous Luminal Diameter (SLD) and the Germinal Epithelial Height (GEH).

\section{Statistical Analysis}

Data were expressed as means \pm standard deviation. One-way Analysis of Variance (ANOVA) followed by Dunnet's post hoc test and independent samples t-test were used to analyze the data. Values of $\mathrm{P}<0.05$ were considered significant.

\section{Results}

\section{Semen Analysis}

The result of the semen analyses for the control bucks (group A) and the danazol dosed bucks (groups B and C) are as presented on Tables 1 and 2. There were significant decreases in volume, mass activity, motility, percentage normal live-dead ratio, morphology and concentration in groups $\mathrm{B}$ and $\mathrm{C}$ bucks compared with group A bucks $(\mathrm{P}<0.05)$. The semen characteristics of the group $\mathrm{C}$ bucks were reversed to normal range (similar to those of group A bucks) two weeks after danazol treatment was withdrawn.

\section{Hormonal Analysis}

The results for the hormonal analyses are as shown on Table 3. There was significant decrease in serum testosterone level in groups $\mathrm{B}$ and $\mathrm{C}$ bucks when compared with those of group $\mathrm{A}$ in week 1, 2, 3 and $4(\mathrm{P}<0.05)$. The FSH serum concentration significantly decreased in groups $\mathrm{B}$ and $\mathrm{C}$ bucks when compared with group A bucks in week 1, 2, 3 and 4. Also, LH level was significantly lowered in groups B and C bucks than in group A bucks in weeks 1, 2,3 and 4.

\section{Gross Morphometric Studies}

The results for the gross morphometric studies are as shown on Table 4. The weight and volume of the testes of group B bucks were significantly decreased compared with those of the group A bucks $(\mathrm{P}<0.05)$.

\section{Histo-Morphometric Studies}

The results of the histomorphometric studies are as shown on Table 5. There were no significant differences in the STD of group A and B bucks' right testes and left testes $(\mathrm{P}<0.05)$. But there was significant decrease in SLD of the right testes of group B bucks compared with group A bucks and similarly for the left testes. There were also significant decreases in GEH of the group B right testes and left testes compared with those of group A bucks. 
Table 1. Semen characteristics of control and West African Dwarf bucks dosed with danazol at 20mg/kg body weight.

\begin{tabular}{|c|c|c|c|c|c|c|}
\hline $\begin{array}{c}\text { Semen } \\
\text { characteristics }\end{array}$ & $\mathrm{N}$ & Group & $\begin{array}{l}\text { Week } \\
\text { One }\end{array}$ & $\begin{array}{l}\text { Week } \\
\text { Two }\end{array}$ & $\begin{array}{l}\text { Week } \\
\text { three }\end{array}$ & $\begin{array}{l}\text { Week } \\
\text { Four }\end{array}$ \\
\hline \multirow{3}{*}{ Colour } & 6 & $\mathrm{~A}$ & Cream & Cream & Cream & Cream \\
\hline & 6 & $\mathrm{~B}$ & Light cream & Grey & Grey & Grey \\
\hline & 6 & $\mathrm{C}$ & Light cream & Grey & Grey & Grey \\
\hline \multirow{3}{*}{ Volume (ml) } & 6 & $\mathrm{~A}$ & $0.4 \pm 0.03 * a b c$ & $0.3 \pm 0.06^{* a b c}$ & $0.3 \pm 0.09 * a b c$ & $0.4 \pm 0.05^{* a b c}$ \\
\hline & 6 & B & $0.2 \pm 0.07 * \mathrm{ba}$ & $0.2 \pm 0.05 * \mathrm{ba}$ & $0.2 \pm 0.04 * \mathrm{ba}$ & $0.2 \pm 0.01 * \mathrm{ba}$ \\
\hline & 6 & $\mathrm{C}$ & $0.2 \pm 0.09 * \mathrm{ca}$ & $0.2 \pm 0.07 * \mathrm{ca}$ & $0.2 \pm 0.05^{* \mathrm{ca}}$ & $0.2 \pm 0.04 *$ ca \\
\hline \multirow{3}{*}{ Mass activity } & 6 & A & $4.6 \pm 0.41 * \mathrm{abc}$ & $4.5 \pm 0.38 * \mathrm{abc}$ & $4.4 \pm 0.61 * a b c$ & $4.6 \pm 0.46^{* a b c}$ \\
\hline & 6 & $\mathrm{~B}$ & $1.7 \pm 0.26^{* \mathrm{ba}}$ & $1.5 \pm 0.31 * \mathrm{ba}$ & $1.1 \pm 0.14^{* b a}$ & $0.9 \pm 0.32 *$ ba \\
\hline & 6 & $\mathrm{C}$ & $1.9 \pm 0.13^{* \mathrm{ca}}$ & $1.6 \pm 0.27 * \mathrm{ca}$ & $1.3 \pm 0.09 * \mathrm{ca}$ & $1.0 \pm 0.24 * \mathrm{ca}$ \\
\hline \multirow{3}{*}{ Motility (\%) } & 6 & $\mathrm{~A}$ & $93 \pm 5.06^{* a b c}$ & $92 \pm 4.97 * a b c$ & $94 \pm 5.13^{* a b c}$ & $93 \pm 4.35^{* a b c}$ \\
\hline & 6 & $\mathrm{~B}$ & $52 \pm 3.22 *$ ba & $46 \pm 2.67 *$ ba & $41 \pm 3.16^{* \text { ba }}$ & $38 \pm 2.65^{* b a}$ \\
\hline & 6 & $\mathrm{C}$ & $50 \pm 4.09 *$ са & $47 \pm 3.53$ *ca & $43 \pm 5.26^{* \mathrm{ca}}$ & $40 \pm 3.17$ *ca \\
\hline \multirow{3}{*}{ Morphology (\%) } & 6 & A & $91 \pm 4.08 * a b c$ & $93 \pm 5.14 * a b c$ & $92 \pm 4.71 * a b c$ & $92 \pm 4.67 * a b c$ \\
\hline & 6 & B & $66 \pm 2.94 * \mathrm{ba}$ & $60 \pm 3.72 *$ ba & $52 \pm 2.61 *$ ba & $43 \pm 2.09 * \mathrm{ba}$ \\
\hline & 6 & $\mathrm{C}$ & $68 \pm 4.01 * \mathrm{ca}$ & $62 \pm 3.54 * \mathrm{ca}$ & $55 \pm 3.87 *$ ca & $47 \pm 4.28$ *a \\
\hline \multirow{3}{*}{$\begin{array}{l}\text { Live-dead ratio } \\
(\%)\end{array}$} & 6 & $\mathrm{~A}$ & $90 \pm 5.03 * a b c$ & $92 \pm 4.6^{* a b c}$ & $91 \pm 4.82^{* a b c}$ & $92 \pm 5.01 * a b c$ \\
\hline & 6 & B & $64 \pm 2.73 * \mathrm{ba}$ & $59 \pm 2.33 *$ ba & $55 \pm 3.16^{* \text { ba }}$ & $51 \pm 2.63 *$ ba \\
\hline & 6 & $\mathrm{C}$ & $63 \pm 3.15^{* \text { ca }}$ & $58 \pm 2.66^{* \text { ca }}$ & $54 \pm 2.97 *$ са & $51 \pm 3.41 *$ ca \\
\hline \multirow{3}{*}{$\begin{array}{l}\text { Concentration }\left(10^{9}\right. \\
\text { sperm cells } / \mathrm{ml})\end{array}$} & 6 & A & $1.88 \pm 0.14^{* a b c}$ & $1.79 \pm 0.12 * a b c$ & $1.86 \pm 0.09 * a b c$ & $1.90 \pm 0.06^{* a b c}$ \\
\hline & 6 & $\mathrm{~B}$ & $1.53 \pm 0.25 * \mathrm{ba}$ & $1.36 \pm 0.19 *$ ba & $1.14 \pm 0.23 * \mathrm{ba}$ & $0.94 \pm 0.16^{* \text { ba }}$ \\
\hline & 6 & $\mathrm{C}$ & $1.52 \pm 0.72 * \mathrm{ca}$ & $1.37 \pm 0.60 * \mathrm{ca}$ & $1.13 \pm 0.25^{* \mathrm{ca}}$ & $1.02 \pm 0.38 * \mathrm{ca}$ \\
\hline
\end{tabular}

*Significant at $\mathrm{P}<0.05 ;{ }^{* a b c}$ when row a is compared with rows $\mathrm{b}$ and $\mathrm{c}$.

Table 2. Semen analyses of West African Dwarf bucks post-withdrawal of danazol treatment of 20mg/kg body

\begin{tabular}{|c|c|c|c|c|c|}
\hline Semen Characteristics & $\mathrm{N}$ & Week 1 & Week 2 & Week 3 & Week 4 \\
\hline Colour & 6 & Grey & Cream & Cream & Cream \\
\hline Volume (ml) & 6 & $0.2 \pm 0.02 *$ abcd & $0.3 \pm 0.08 * \mathrm{ba}$ & $0.4 \pm 0.03 * \mathrm{ca}$ & $0.4 \pm 0.09 * \mathrm{da}$ \\
\hline Mass activity & 6 & $1.2 \pm 0.31 * \mathrm{abcd}$ & $4.1 \pm 0.52 *$ ba & $4.4 \pm 0.36^{* \mathrm{ca}}$ & $4.5 \pm 0.18 * \mathrm{da}$ \\
\hline Motility (\%) & 6 & $40 \pm 1.82 *$ abcd & $89 \pm 3.25 *$ ba & $91 \pm 2.47 * \mathrm{ca}$ & $92 \pm 3.52 *$ da \\
\hline Morphology (\%) & 6 & $41 \pm 1.58 *$ abcd & $90 \pm 3.27 * \mathrm{ba}$ & $92 \pm 2.58 * \mathrm{ca}$ & $92 \pm 2.91 * \mathrm{da}$ \\
\hline Live-dead ratio $(\%)$ & 6 & $50 \pm 3.41 * a b c d$ & $91 \pm 4.02 *$ ba & $92 \pm 1.83 * \mathrm{ca}$ & $91 \pm 3.65 *$ da \\
\hline Concentration $\left(10^{9}\right.$ sperm cells $\left./ \mathrm{ml}\right)$ & 6 & $0.9 \pm 0.20 *$ abcd & $1.9 \pm 0.22 * \mathrm{ba}$ & $1.9 \pm 0.35^{* \mathrm{ca}}$ & $2.1 \pm 0.24 * \mathrm{da}$ \\
\hline
\end{tabular}

*Significant at $\mathrm{P}<0.05$; when column a was compared with columns $\mathrm{b}, \mathrm{c}$ and $\mathrm{d}$.

Table 3. Hormonal analyses of control and West African Dwarf bucks dosed with danazol at 20mg/kg body weight.

\begin{tabular}{|c|c|c|c|c|c|}
\hline Hormones & Group & Week 1 & Week 2 & Week 3 & Week 4 \\
\hline \multirow{3}{*}{ Testosterone (ng/ml) } & $\mathrm{A}$ & $4.70 \pm 0.11 * a \mathrm{abc}$ & $4.69 \pm 0.12^{* a b c}$ & $4.80 \pm 0.12 * a b c$ & $4.74 \pm 0.16^{* a b c}$ \\
\hline & B & $1.87 \pm 0.03 * \mathrm{ba}$ & $1.45 \pm 0.04 * \mathrm{ba}$ & $1.11 \pm 0.06^{* \mathrm{ba}}$ & $0.90 \pm 0.05^{* \mathrm{ba}}$ \\
\hline & $\mathrm{C}$ & $1.90 \pm 0.05 * \mathrm{ca}$ & $1.43 \pm 0.07 * \mathrm{ca}$ & $1.13 \pm 0.02 * \mathrm{ca}$ & $0.92 \pm 0.04 * \mathrm{ca}$ \\
\hline \multirow{3}{*}{ FSH (mMol/ml) } & A & $3.06 \pm 0.15 * a b c$ & $2.97 \pm 0.17 * a b c$ & $2.89 \pm 0.10 * \mathrm{abc}$ & $3.03 \pm 0.03 * \mathrm{abc}$ \\
\hline & B & $0.87 \pm 0.02 * \mathrm{ba}$ & $0.74 \pm 0.04 * \mathrm{ba}$ & $0.56 \pm 0.02 * \mathrm{ba}$ & $0.35 \pm 0.03 * \mathrm{ba}$ \\
\hline & $\mathrm{C}$ & $0.85 \pm 0.07 * \mathrm{ca}$ & $0.76 \pm 0.05 * \mathrm{ca}$ & $0.55 \pm 0.03^{* \mathrm{ca}}$ & $0.36 \pm 0.02 * \mathrm{ca}$ \\
\hline \multirow{3}{*}{$\mathrm{LH}(\mathrm{mMol} / \mathrm{ml})$} & A & $2.40 \pm 0.18 * a b c$ & $2.68 \pm 0.12 * a b c$ & $2.75 \pm 0.10 * a b c$ & $2.62 \pm 0.15 * a b c$ \\
\hline & B & $0.90 \pm 0.05 * \mathrm{ba}$ & $0.77 \pm 0.03 * \mathrm{ba}$ & $0.56 \pm 0.02 *$ ba & $0.38 \pm 0.06^{* \mathrm{ba}}$ \\
\hline & $\mathrm{C}$ & $0.92 \pm 0.04 * \mathrm{ca}$ & $0.76 \pm 0.02 * \mathrm{ca}$ & $0.58 \pm 0.03^{* \mathrm{ca}}$ & $0.35 \pm 0.05^{* \mathrm{ca}}$ \\
\hline
\end{tabular}

*Significant at $\mathrm{P}<0.05$ when row a was compared with row b and c, FSH- Follicle Stimulating Hormone; LH- Luteinizing Hormone.

Table 4. Weight and volume of the testes of control and West African Dwarf bucks dosed with danazol at 20mg/kg body weight.

\begin{tabular}{l|ccccc}
\hline \multicolumn{1}{c|}{ Parameters } & $\mathrm{N}$ & WRT $(\mathrm{kg})$ & VRT $\left(\mathrm{cm}^{3}\right)$ & WLT $(\mathrm{kg})$ & VLT $\left(\mathrm{cm}^{3}\right)$ \\
\hline Control group & 6 & $28.6 \pm 1.3^{* \mathrm{ab}}$ & $28.2 \pm 1.1^{* \mathrm{ab}}$ & $28.4 \pm 1.2^{* \mathrm{ab}}$ & $28.7 \pm 1.0^{* \mathrm{ab}}$ \\
Experimental group & 6 & $25.9 \pm 0.4^{* \mathrm{ba}}$ & $25.6 \pm 0.3^{* \mathrm{ba}}$ & $25.7 \pm 0.3^{* \mathrm{ba}}$ & $25.8 \pm 0.4^{* \mathrm{ba}}$ \\
\hline
\end{tabular}

*Significant at P<0.05 when row a was compared with row b, WRT - weight of right testes; VRT - volume of right testes; WLT - weight of left testes;

VLT - volume of left testes

Table 5. Histo-morphometry of the testes of control and West African Dwarf bucks dosed with danazol at 20mg/kg body weight

\begin{tabular}{lccccc}
\multicolumn{1}{c}{ Parameters } & $\mathrm{N}$ & $\begin{array}{c}\text { Control Right } \\
\text { testis }(\mu \mathrm{m})\end{array}$ & $\begin{array}{c}\text { Control Left } \\
\text { testis }(\mu \mathrm{m})\end{array}$ & $\begin{array}{c}\text { Danazol } \\
\text { Right testis }\end{array}$ & $\begin{array}{c}\text { Danazol } \\
\text { Left testis }\end{array}$ \\
\hline Seminiferous tubular diameter & 12 & $572.5 \pm 26.1$ & $580.7 \pm 28.2$ & $565.9 \pm 23.6$ & $569.2 \pm 24.7$ \\
\hline Seminiferous luminal diameter & 12 & $247.2 \pm 25.8^{* \text { acd }}$ & $251.6 \pm 26.2^{* \text { bcd }}$ & $121.3 \pm 15.7^{* \text { cab }}$ & $122.8 \pm 13.8^{* \text { dab }}$ \\
\hline Germinal epithelial height & 12 & $186.2 \pm 24.6^{* \text { acd }}$ & $179.8 \pm 23.8^{* \text { bcd }}$ & $114.5 \pm 17.8^{* \text { cab }}$ & $116.9 \pm 14.2^{* \text { dab }}$ \\
\hline
\end{tabular}

*Significant at $\mathrm{P}<0.05$ when column a is compared with columns $\mathrm{b}, \mathrm{c}$ is compared and $\mathrm{d}$. 


\section{Discussion}

This study was conducted to investigate the changes in semen characteristics, hormonal profile and testicular morphometry of West African Dwarf (WAD) goat bucks treated with danazol and its possible usefulness as a contraceptive in WAD goat bucks. We observed that danazol caused a significant reduction in sperm motility, mass activity, concentration, percentage live-dead ratio and normal morphology in WAD goat bucks. However, these semen characteristics were reversed to normal range two weeks post withdrawal of danazol treatment. This is similar to the reports by Lohiya and Sharma (2009) who observed severe reduction for seventy-four days in semen characteristics of rabbit bucks treated with a combination of danazol and testosterone which was reversed to normal range after 115 days post treatment. The difference in the duration of reversal to normal semen picture may be due to the combination of testosterone with danazol in the earlier study and duration of administration of danazol. Danazol also caused a significant decrease in testosterone, FSH and LH concentrations similar to the reports by Van Kroonenburgh et al., (1986) in rats. There was also a significant reduction in the testicular weight and volume of danazol dosed WAD bucks similar to the observations in rats by Alabi et al., (2015). With reference to the fact that testicular volume is an index of spermatogenesis ((Kollin et al., 2006; Raji et al., 2016), part of the reasons for the reduction in semen characteristics due to the effect of danazol observed in the present study may be due to the reduction in testicular volume. We also observed significant reduction in SLD and GEH of the danazol dosed WAD bucks. These are similar to the observations in rats dosed with danazol by Van Kroonenburgh et al. (1986). The reduction GEH may also be implicated in the reduction in semen characteristics since the germinal epithelia are where the germ cells are within the testis (Laoye et al., 2019).

The findings in this study also confirm that danazol has an inhibitory effect on reproduction of male animals. However, these inhibitory effects as stated earlier were reversible in the WAD bucks studied similar to earlier reports (Lohiya and Sharma, 2009). This suggests that danazol could be used as fertility control drug in WAD bucks with effective management. Fertility control may be done to prevent unwanted pregnancy, reduce livestock production (if need be), prevent transfer of diseases and undesired genetic traits or qualities, amongst other reasons. In livestock production, these fertility controls are usually done either by surgical or non-surgical means. However, the non-surgical approach is becoming more preferable in modern day livestock production to replace the invasive method of castration which permanently renders the male animal sterile (Ansari et al., 2017; Fesseha, 2019).

The mechanism of inhibition of spermatogenesis by danazol is still not fully understood. This study based on the various fertility parameters gave a very good clue by speculating the contraceptive mode of action of danazol in the bucks. It is a well-known fact that danazol is a steroid and could interfere with the male androgenic hormones which might be one of its reversible mechanisms. The fact is that the danazol inhibit or suppresses the gonadotrophic hormones this would affect spermatogenesis by decrease in the surge of FSH and LH (Van Kroonenburgh et al., 1986; Oduwole et al., 2018). Danazol could have affected some of the spermatogenic cells as observed in the histomorphometric study. A dose of $20 \mathrm{mg} / \mathrm{kg}$ could cause a reversible decrease in the bioavailability below the steady state level which would terminate the drugs effect in the systemic circulation. This could be the reason for the fertility reversal and improvement of fertility parameters after the danazol withdrawal.

In conclusion, danazol caused a reversible reduction in hormonal and spermatogenetic activities in WAD bucks. Therefore, we suggest that it could be used as a contraceptive in WAD goat bucks.

\section{References}

Alvarez GC, Gómez-Galicia D, Rodríguez-Fragoso L, Marina VM, Dorantes LC, Sánchez-Aleman M, Mendez-Sanchez N, Esparza JR. 2011. Danazol improves thrombocytopenia in $\mathrm{HCV}$ patients treated with peginterferon and ribavirin. Annals of hepathology, 10 (4): 458-468.

Akinloye AK, Abatan MO, Alaka OO, Oke BO. 2002. Histomorphometric and Histopathological Studies on the effect of Calotropis procera (Giant milkweed) on the male reproductive organs of wistar rats. Afric. J. of Biomed. Res., 5: 57-61.

Ansari AS, Badar A, Lohiya NK. 2017. Fertility Control Modalities in Animals: An Overview. BAOJ Vet. Sci., 1: 004.

Bitto II, Akusu MO, Egbunike GN, Akpokodje JU. 2000. The physical characteristics of ovine-caprine ejaculate mixtures and the survival of their spermatozoa in cow's milk extender in the humid tropics. Trop. J. of Anim. Sci., 3: 147-152.

Fesseha H. 2019. Non-surgical sterilization methods in male animals: A review. Vet. Med. Open J. 2019; 4(1): 49-56.

Jana K, Samanta PK, 2011. Clinical Evaluation of Non-surgical Sterilization of Male Cats with Single Intra-testicular Injection of Calcium Chloride. BMC Veterinary Research, 7:39-54.

Kollin C, Hesser U, Ritzen EM, Karpe B. 2006. Testicular growth from birth to two years of age and the effect of orchidopexy at age nine months: a randomized, controlled study. Acta Paediatrica, 95: 318-324.

Laoye BJ, Ishola AO, Mabayoje SO, Ogunlade BO, Olajuyigbe AB. 2019. Histoarchitecture of the Germinal Epithelium of Cyanide Treated Rats. EC Emergency Medicine and Critical Care 3(11): 14-20.

Lauro FV, Francisco DC, Ma LR, Elodia GC. 2011. Activity induced by a danazol derivative on perfusion pressure and coronary resistance in isolated rat heart. Biomedical Research, 22 (3): 289-294.

Lohiya NK, Sharma OP. 2009. Reversible inhibition of spermatogenesis by danazol with combination of testosterone enanthate in rabbit. Andrologia, 16(1): 72-5.

Mbaeri TU, Orakwe JC, Nwofor AM, Oranusi KC, Mbonu OO. 2012. Accuracy of Prader orchidometer in measuring testicular volume. Nig. J. Clin. Prac., 16: 348-351.

Oduwole OO, Peltoketo H, Huhtaniemi IT. 2018. Role of Follicle-Stimulating Hormone in Spermatogenesis. Front. Endocrinol., 9:763-773.

Olukole SG, Oyeyemi MO, Oke BO. 2014. Biometrical and histometrical observations on the testis and epididymis of the African sideneck turtle (Pelusio scastaneus). Eur. J. Anat., 18(2): 102-108.

Raji LO, Ajala OO. 2015. Scrotal Circumference as a Parameter of Breeding age for West African Dwarf Bucks. Turk. J. Agric. Food Sci. and Tech., 3(8): 668-671.

Raji LO, Ajala OO, Ameen SA. 2016. Testicular ultrasound as a breeding soundness examination and biometric tool for west african dwarf buck goats. Slovak J. Anim. Sci., 49(1): 8-16.

Raji LO, Ajala OO, Osuagwuh UI. 2015. Morphological and Morphometric Studies on the Epididymis of West African Dwarf Buck Goat (Capra hircus). J. Vet. Anat., 8(2): 69-80.

Van Kroonenburgh MJ, Beck JL, Vemer HM, Thomas CMG, Rolland R, Herman CJ. 1986. Effects of Danazol on spermatogenesis in adult rats. J. Reprod. Fertil., 77: 23-238. 